\title{
Література:
}

1. Антонова O.С. Сутність поняття креативності: проблеми та пошуки: монографія / за ред. О.А. Дубасенюк. Житомир, 2012. С. 14-41.

2. Колток, Л., Іваник, Н. Упровадження STEM-освіти в освітній процес Нової української школи. Актуальні питання гуманітарних наук: міжвузівський збірник наукових праць молодих вчених Дрогобицького державного педагогічного університету імені Івана Франка. № 27. Т. 3. С. 133-136.

3. Концепція реалізації державної політики у сфері реформування загальної середньої освіти «Нова українська школа» на період до 2029 року. Київ, 2016. URL: https://osvita.ua/legislation/Ser_osv/54258/ (дата звернення: 30.09 .2021$)$.

4. Упровадження STEM-освіти в умовах інтеграції формальної і неформальної освіти обдарованих учнів: методичні рекомендації / Н.I. Поліхун, К.Г. Постова, І.А. Сліпухіна, Г.В. Онопченко, О.В. Онопченко. Київ, 2019. 80 с.

5. STEAM-освіта: інноваційна науково-технічна система навчання. URL: http://ippo.kubg.edu.ua/content/11373 (дата звернення: 28.09.2021).

DOI https://doi.org/10.30525/978-9934-26-146-6-33

\section{USE OF INTERNET RESOURCES IN PROCESS OF TEACHING AND STUDYING MARITIME ENGLISH}

\author{
Tishchenko O. A., Temerbek A. O.
}

Senior Lecturers, Navigation and Ship Handling Chair

Azov Maritime Institute of National University «Odessa Maritime Academy» Mariupol, Ukraine

Modern society makes high demands on students' professional education in mastering foreign languages. Knowledge of a foreign language is necessary to be a competitive person in the market labour. It became not just an object of desire, but an object of life necessity and demand. Hence there are new requirements for the use of new technologies in teaching and the study of the English language. The use of modern information technology (IT) in education is one of the most important and sustainable trends in the development of the modern educational process in professional education and one of the most effective ways in mastering vocabulary in the specialty. IT technologies are the methods of receiving and processing the information. 
Among such technologies, a special place is occupied by the interactive computer programmes and systems that activate all types of human activities: mental, speech, physical, perceptual. Interactive testing systems analyse the quality of knowledge. Therefore, their application allows one to build a training scheme in which a reasonable combination of conventional and computer forms of organizing the educational process gives a new quality in the assimilation of the knowledge system. The introduction of IT technologies into the educational process exempts the teacher from the routine work and makes it possible to create reference and illustrative material presented in a variety of ways. It allows you to intensify the educational process, increases the speed of perception, understanding and the depth of mastering the discipline, and develop erudition.

The teaching form with the use of computer teaching aids is based on a certain concept, the main subjects of which are as follows:

1. The learning process is based mainly on the student's independent cognitive activity. For this purpose, it is necessary to ensure maximum student access to educational information. The teacher becomes a tutor advising in the training process and organizing quality control of students' knowledge. Application of network technologies (e-mail, video and sound conference, etc.) is one of the forms of organizing such control today.

2 . The student's cognitive activity must be active. The proactive nature of computer-based learning is closely related to the principle of self-education. The self-education is impossible without a student active participation in the educational process, which is determined by his internal motivation, expressed as a desire to learn.

3. Teaching should be student-centered. This concept presupposes the differentiation and individualization of teaching, depending on the psychological and pedagogical trainee properties. Such personalized learning is possible only on the basis of high education technologies, based on computer tools and technologies. In this respect, the concept of distance and time loses primary meaning: it becomes unimportant where the source of information is - in the next room or in another city.

The specialty 271.01 Navigation and Ship handling involves the formation of both general and professional competencies of students. The results of mastering the academic discipline Professional English is the ability to use information and communication technologies in professional activities, to master written and oral communication in the state and/or foreign language, etc. These skills are components of the thinking systems of a modern person living in a huge information space.

The named competencies are formed during the entire period of mastering the Professional English. This is also facilitated by the electronic information 
and educational environment in Azov Maritime Institute of National University «Odessa Maritime Academy». Each cadet/student mastering the specialty Navigation gets access to the materials of the electronic courses. The main goal of the course is to provide control of independent work. Due to the possibilities of modern Internet resources, almost unlimited opportunities open up for students to study English independently.

At our lessons of Professional English, we use international maritime conventions, audio materials, Internet resources that enable not only to find out useful information but also to broaden the glossary of the course by the students/cadets themselves. They carry out an independent search on the Internet as well as use printed publications of the manuals on which they work in the classroom.

Tasks of the electronic courses used in Azov Maritime Institute of National University "Odessa Maritime Academy» include not only the Internet resources of the modules, but also the printed editions of that educational literature used in the classroom; listening to audio materials on the topic and question-and-answer exercises using new vocabulary; reading and analysing professional articles; performing various kinds of tests with using professional vocabulary; project preparation and finally discussion. In such form of work as a discussion, cadets and students express their opinions on the essence of the course that enables them to communicate outside the classroom through the Internet. They use that accumulated vocabulary, which they independently learned, performing various searching tasks.

For example, Marlins Learning Portal is very useful for the future navigators. Founded in 1994, Marlins offers training and evaluation solutions for the maritime industry, including cargo and cruise ships, superyachts and the offshore sector. It is a leading provider of Maritime English Language tests to sailors worldwide. The catalogue of training courses offers interesting, modern educational content, which is aimed at improving the knowledge of seafarers and improving the efficiency of ships. On this site, cadets and students of Azov Maritime Institute of National University «Odessa Maritime Academy» have the opportunity to use the Learning Portal to take training courses and see their progress in mastering the specialty:

1. An Introduction to Standard Marine Communication Phrases;

2. Carriage of Dangerous Cargoes in Bulk (Carriage of Dangerous Goods in Bulk);

3. Enclosed Spaces;

4. Firefighting Equipment Maintenance with Fire Aid;

5. IMDG Code / HAZMAT (International Dangerous Goods Code / Hazardous Materials);

6. Roles and Responsibilities of the Safety Officer; 
7. Safe Mooring;

8. Search and Rescue;

9. Security Duties for Seafarers (UK MCA Flag Approved).

The International Maritime Language Program (IMLP) contains an English-language textbook with a variety of texts, assignments, and projects, a DVD containing many lectures and tests at various levels, and a full set of standard marine colloquial phrases (SMCP). This program was designed for cadets and students of maritime institutions of higher education of any level, for on-board training and distance learning. IMLP covers all aspects of the maritime industry, reflecting the modern communicative methodology of language teaching and learning.

The program consists of 8 sections of maritime English, which are used in VHF communication, general knowledge of the ship, technology, navigation, safety, documents, correspondence and practical grammar. Our experience with this program has shown that it is well suited for compliance with maritime communication requirements, as set out in the relevant sections of the International Convention on the Training and Certification of Seafarers and Watchkeeping (STCW).

In conclusion we would like to mention that it is very important for every teacher to increase the efficiency of the lesson. The lesson will be effective when it will be primarily interesting for both the teacher and the cadets/students. It should have a communicative focus; each cadet/student should feel like a direct participant in the foreign language speech activity.

The possibilities of using the Internet resources are enormous. The global Internet creates conditions for obtaining any necessary information for students and teachers located anywhere in the world. Such websites as http://www.soundsenglish.com, http://www.fluentenglish.ru, http://www.bbc.co.uk/worldservice/learningenglish and many others provide a wide variety of tasks, texts, audio materials for teaching not only lexical units, but also other aspects of the language in any level. Cadets/students can take part in testing, quizzes, competitions held on the Internet, correspond with peers from other countries, participate in chats, video conferencing, etc.

\section{References:}

1. International Maritime Language Program [Електронний ресурс]. Доступно: http://www.imlp-books.com/?action=view\&cid=9\&aid=16\&lid=2

2. Marlins Learning Portal [Електронний pecypc]. Доступно: https://learn.marlins.co.uk/

3. Биков В.Ю. Сучасні завдання інформатизації освіти, Інформаційні технології і засоби навчання, № 1 (15), 2010. [Електронний 
pecypc]. Доступно: https://journal.iitta.gov.ua/index.php/itlt/article/view/ $25 / 13$

4. Міжнародна конвенція про підготовку і дипломування моряків та несення вахти 1978 року. [Електронний ресурс]. Доступно: http://zakon0.rada.gov.ua/laws/show/995_053.

5. Осадчий В.В., Осадча К.П. Сучасні реалії і тенденції розвитку інформаційно-комунікаційних технологій в освіті, Інформаційні технології і засоби навчання, т. 48, № 4, С. 47-57, 2015.

DOI https://doi.org/10.30525/978-9934-26-146-6-34

\title{
МОДЕЛІ ФАХОВО ОРІЄНТОВАНОГО НАВЧАННЯ ХІМІЧНИХ ДИСЦИПЛІН
}

\author{
Філіппова Л. В. \\ кандидат хімічний наук, доктор педагогічних наук, дочент, \\ доиент кафедри медичної та загальної хімії \\ Національний медичний університет імені О. О. Богомольия \\ м. Київ, Украӥна
}

Сьогоднішній запит щодо якості навчання хімічних дисциплін та методика навчання хімічних дисциплін як вагома складова фармацевтичної освіти потребує постійного творчого пошуку, оновлення змісту, форм та методів навчання, динамічних змін у підходах до впровадження інноваційних технологій навчання та їх ефективного поєднання з традиційними навчальними технологіями. Сучасний запит до якості навчання хімічних дисциплін $\mathrm{M}(\Phi) 3 В О$ значною мірою обумовлюється актуальними i перспективними потребами фармацевтичної галузі, прогнозованими вимогами до професійної компетентності і конкурентоспроможності фахівців на ринку праці, а його реалізація - ефективною взаємодією у тріаді «освіта-наука-виробництво».

При створенні моделі фахово орієнтованого навчання базових хімічних дисциплін нами розроблена методика проведення усіх форм навчальних занять та сконструйована структура навчально-методичного комплексу. Однією з визначальних детермінант змісту освіти є ії мета, яка $є$ соціально та історично обумовленою, оскільки визначається суспільними запитами. Це означає, що зміст освіти формується відповідно до вимог життя, виробництва, рівня розвитку наукового знання. В Законі Україні «Про вищу освіту» (2014) [1] чітко 126 